\title{
THE INSURANCE OF MEDICAL LOSSES
}

\author{
RICHARD S. L. RODDIS* AND RICHARD E. STEWART**
}

We are educated by the American creed of accomplishment to believe that every problem, however defined, is susceptible to solution through the application of reasoned effort. Difficult problems simply are those which demand greater measures of reasoned effort to achieve solution. As a corollary, it is supposed that difficulty and complexity are the same, so that a difficult problem must be a complex problem.

Resignation to unsatisfying states of affairs is not a prized trait in the American character. Hence, when a difficult problem proves intractable despite the earnest expenditure of enough reasoned effort to overcome coinplexity, an almost automatic response is to proceed to expose villains, whose dishonesty, stupidity, or greed have subverted reasoned effort.

\section{Defining the Bounds of the Problem}

The medical malpractice insurance problem lias captured the attention of the body politic. ${ }^{1}$ It is analyzed in the daily newspapers. It is the subject of extended conferences and studies by a great array of

* Dean and Professor of Law, University of Washington Law School; Insurance Commissioner, State of California, 1966-68; Member of the California Bar; Director, Unigard Mutual Insurance Company.

** Senior Vice President, Director and Chief Financial Officer, Chubb \& Son Inc.; Superintendent of Insurance, State of New York, 1967-70; Member of the New York Bar.

The authors are indebted for their able and generous assistance to Warren P. Cooper, Vice President and Actuary of Chnbb \& Son Inc. at the time this article was written and now Vice President and Actuary of INA Corp., and to John K. Cowperthwaite, Jr., Assistant Vice President of Chubb \& Son Inc. in charge of underwriting professional liability insurance.

THE FOLLOWING CITATION WILL BE USED IN THIS ARTICLE:

U.S. Dep'T of Health, Education and Welfare, Report of the Secretary's Commission on Medical Malpractice (1973) [hereinafter cited as Medical MalPRACTRCE REPORT].

1. See Staff of House Comm. on Interstate and Foreign Commerce, 94th Cong., 1st Sess., An Overview of Medical Malpractice (Comm. Print 1975). For a discussion of state legislative efforts to deal with the problem, see Comment, An Analysis of State Legislative Responses to the Medical Malpractice Crisis, 1975 DUKR L.J. 1417. 
experts. ${ }^{2}$ Various legislatures either have or are planning to conduct special sessions to deal only with it. ${ }^{3}$ In pursuit of a solution, there is no want of reasoned effort. Yet it remains a difficult problem of baffling complexity and the search for villains is intense. The fact of the matter is that the medical malpractice insurance problem is not particularly complex and villainy plays only a minor role in it. That does not mean, however, that it is not an intractable problem-at least if its solution takes the form in which any of the organized, involved groups cast it.

\section{The Medical Loss Question Generally}

Although this Article will concentrate on medical malpractice in its insurance aspect, that aspect, unavoidably parochial, is no place to begin. We will understand the insurance aspect better if we look first at the broader subject, of which insurance is a part. The subject is the totality of the legal and business arrangements provided by our society for allocating the financial burden of the losses occurring in the administration of health care. For our purposes, a medical loss occurs whenever a person submits to diagnosis, advice, or treatınent (including nontreatment) from one or more professional or institutional providers of health care and winds up being in worse condition than if measures of diagnosis, advice, or treatment other than the ones pursued had been administered.

This definition of loss is very broad, being cast solely in terms of health care causation. It says nothing about whether the loss was culpably caused or about its economic valuation. Loss, so defined, is not the sanue as legal hability for damages and is not the loss with which the providers' insurers are concerned. All conceptions of loss which go beyond this rudimentary definition are to a greater or lesser extent a product of decisions made in the processes of the legal and business arrangements created by society for determining how the financial impacts of the original loss shall be allocated.

It is mportant to think of the loss valuation, allocation, and distribution arrangements prescribed by the society as a total and interrelated system. ${ }^{4}$ There is always a loss allocation system, even in a hypothetical society which makes no provision, formal or informal, for shifting or

2. See, e.g., House SUbcomm. on HeAlth and ENVIronment of the COMMTTteE on Interstate and Foreign Commerce, National Conference on Medical MalPRACTICE (Subcomm. Print 1975).

3. N.Y. Times, Aug. 13, 1975, at 53, col. 3; id. July 1, 1975, at 32, col. 1.

4. See generally G. Calabresi, The Costs of Accidents: A Legal and EcoNOMIC ANALYSIS (1970). 
distributing the burden of loss. In such a society, all loss is allocated by default so as to stay with the person (and his dependents) upon whom it first fell. The legal structure, both by its prescribed substantive and procedural rules and by the actual operation of its processes, merely functions to value and allocate the financial burden of medical loss. Similarly, the array of insurance and other private and governmental financial arrangements merely functions further to reallocate and distribute the financial consequences of loss. All of the components of the systen interact in ways which progressively alter the economic ineaning of loss, fragmenting, shifting, and dispersing the impact of the loss in a myriad of directions.

This can be illustrated by an example. A patient, whose condition has been worsened in the sense we origimally postulated as a medical loss, asserts a claim against his physician contending that the physician performed with less than the appropriate level of competence. Because of his worsened condition, the patient incurred $\$ 5,000$ of additional medical expenses and lost $\$ 5,000$ of imcome which he otherwise would have earned. He also experienced pain and inconvenience which, after consultation with his lawyer, he decided was worth $\$ 20,000$. In some other cultures, pam and inconvenience would not be treated as economically cognizable loss but our society adheres to the notion that these psychic detriments are susceptible to economic valuation for conipensation purposes. ${ }^{5}$

The additional medical expense has been paid by the patient's experience-rated, employer-provided group medical plan and $\$ 2,000$ of the lost earnings has been reimbursed under a disability income policy individually purchased by the patient. Eventually, a trial results in a judgment for the plaintiff in the amount of $\$ 15,000$. Of this amount, $\$ 7,500$ goes to recoinpense the plaintiff's lawyer, who handled the case on a contingent fee basis, and to pay other expenses of prosecuting the claim. Another $\$ 2,500$ goes to the group health plan in agreed satisfaction of its contractual subrogation claim. In addition to paying the judgment, the physician's malpractice insurer has expended $\$ 5,000 \mathrm{~m}$ defense of the claim.

The amounts expended by the malpractice insurer eventually are reflected as a component of the future rates paid by the physician and others in his rate class. To the extent the insurer's rates are inadequate, the cost is borne indirectly by shareholders or other classes of policyholders. Since the physician considers his imsurance costs in determining the appropriate level of his fees, those costs are passed on to his

5. See C. McCormick, Handboor on the LaW of Damages $\$ 88$ (1935). 
patient population in substantial part, though perhaps subject to soine adjustment lag. To the extent that they are not passed on as fee increases, they are borne partly by the physician as a reduction in net income and partly by other income taxpayers generally since the insurance premiums are a deductible business expense. ${ }^{6}$ To the extent malpractice insurance premiums are passed on as a component of patient fees, the greater part winds up being paid by the various private and governmental health care expense reimbursement systems covering the patient population. ${ }^{7}$ The net amounts paid by the group health plan are absorbed into future rates charged to the employer by the plan and eventually reflected in the prices paid by the public for the employer's products. Viewed as a labor cost, the costs of the plan are borne by employees as a substitute for what might have been negotiated as higher wages. ${ }^{8}$ The amount paid by the disability insurance carrier is reflected in its future rates and distributed over its insured population.

There are two points to all of this. First, "loss" appears in several perspectives and forms. The patient thought his loss was $\$ 30,000$, but if we assume that the jury thought it was compensating him mitially for out-of-pocket costs and then for pain and suffering, his loss has been valued at $\$ 15,000$. Of course, the jury may also have discounted the amount of damages because of uncertainty on the hability issue, ${ }^{9}$ just as other juries may magnify the pain and suffering award in cases where they view the physician's conduct as morally, rather than merely technically, culpable. ${ }^{10}$ And the jury may have been consciously attempting to shift a portion of the patient's presumed legal expenses. ${ }^{11}$ In any

6. INT. Rev. CODE OF 1954, § 162(a).

7. A study of health care expenditures indicated that government programs contributed 37.6 percent of total personal health care expenditures in 1974, while private health insurers paid 25.6 percent of the national total. Worthington, National Health Care Expenditures, 1929-74, 38 Soc. Sec. Bull. 3, 16 (Table 6) (Feb. 1975). 818.

8. Cf. Larson, Sex Discrimination As To Maternity Benefits, 1975 Duke L.J. 805,

9. Kalven, The Jury, The Law, and the Personal Injury Damage Award, 19 Oнто ST. L.J. 158, 167 (1958). Where the trial judge or an appellate court is able to determine that a jury's damage award represents a compromise on the liability issue, the verdict will be overturned. See, e.g., Siminons v. Fish, 210 Mass. 563, 571-72, 97 N.E. 102,106 (1912) ( $\$ 200$ award for the loss of an eye by a 21-year-old man overturned as a compromise on the liability issue). See also J. Moore, Moore's Federal Practice If 59.08[4], at 59-127 to 59-128 n.13 (2d ed. 1974).

10. Kalven, supra note 9, at 165-67; Plant, Damages for Pain and Suffering, 19 Orro Sr. L.J. 200, 206 (1958); see also Van Gordon v. United States, 91 F. Supp. 834 (W.D. Mo. 1950).

11. Jaffe, Damages for Personal Injury: The Impact of Insurance, 18 LAW \& Contemp. Рroв. 219, 234-35 (1953); C. MCCormick, supra note 5, at 277. For a criti- 
event, the patient did not come off badly with a net recovery of $\$ 12,000$, but of course $\$ 4,500$ came from sources other than the physician's insurer. ${ }^{12}$ Loss (including the expenses of allocating and otherwise administering the loss) from the standpoint of the malpractice insurer was $\$ 20,000 .^{13}$ Total loss passing through all insurance systems was in excess of $\$ 27,000$, again including loss administration expense. ${ }^{14}$

Second, the loss ultimately was widely, though perhaps not very efficiently, dispersed over random elements of the whole population. Only in a very narrow perspective can one think of the economic consequences of the situation simply in terms of a loss paid by the malpractice insurer and premiums paid by physicians. The real result accoinplished by the total loss allocation and distribution system is much broader.

\section{The Insurance Question Generally}

In order to write any specified line of casualty insurance coverages an insurer must inake a commitment of capital and possess the specialized organizational capability to deal with the line. The necessity for capital commitment results from the social mandate of solidity in the insurance enterprise, ${ }^{15}$ and from the regulatory accounting requirement that the insurer initially establish the full amount of the premium for a policy as a liability ("unearned premium reserve") although it incurs inost of the expenses attendant to the underwriting of the policy at the outset. ${ }^{16}$

cism of this jury tendency, see Morris, Liability for Pain and Suffering, 59 ColuM. L. REV. 476, 477 (1959).

12. From the jury award of $\$ 15,000$, the patient has received $\$ 5,000$ ( $\$ 15,000$ less $\$ 7,500$ for the lawyer and the subrogated $\$ 2,500$ ). In addition, he has received $\$ 5,000$ from the group medical plan and $\$ 2,000$ in disability income, for a total of $\$ 12,000$. The $\$ 4,500$ from other sources consists of the $\$ 2,000$ disability income and the net $\$ 2,500$ payment from the group health plan.

13. The figure represents the $\$ 15,000$ award and the $\$ 5,000$ litigation expense.

14. Of the total, $\$ 20,000$ passed through the malpractice insurer, $\$ 5,000$ through the medical group plan, and $\$ 2,000$ through the disability imcome policy.

15. J. Hanson, R. Dineen \& M. Johnson, Monitorna Competition: A Means of Regulatting the Property and Liability Insurance Business 92-93 (1974). See Kimball, The Regulation of Insurance, in INSURANCE, GoVERNMENT, AND SOCIAL POLICY 3, 5-6 (S. Kimball \& H. Denenberg eds. 1969); Kimball, The Purpose of Insurance Regulation: A Preliminary Inquiry in the Theory of Insurance Law, 45 MINN. L. REv. 471, 477-78 (1961).

16. See E. Patrerson, Essentials of Insurance Law 25 (2d ed. 1957):

The unearned premium reserve at the date of the [financial] statement is the amount that would be needed by the imsurer to repay all holders of outstanding insurance contracts if on that date the insurer elected to cancel all such contracts and to refund, as the contracts required, "pro rata," i.e. that proportion of the premium paid that the period then to be run bears to the total 
The goal of financial stability for the insurance enterprise further dictates that an insurer maintain a reasonably proportionate relationship between premium volume and surplus. ${ }^{17}$ Given a stable level of premium writings without net loss, ${ }^{18}$ the potential surplus drain of new writings is offset by the recapture from reserve of the prepaid expense on earlier policies. ${ }^{10}$ But expansion of the level of premium writings results in a net drain on surplus unless surplus concurrently is augmented either through the commitinent of additional capital from external sources or through the realization of net profits from underwriting and investinent operations. ${ }^{20}$ By the same token, erosion of surplus resulting from net losses in underwriting and imvestment operations reduces the potential volume of insurance which the insurer can write. Hence, although the relationship between premium volume and surplus is not a rigidly prescribed one and is influenced by a number of other variables, there is a point at which either expansion of writings or surplus erosion from operational losses constrains further writings. Viewed either from the standpoint of an individual insurer or of the industry as a whole, there is an ultimate limit which the total capital committed to the insurance enterprise imposes on the aggregate volume of its insurance

period of risk prescribed in the contract. This is usually the largest single liability item in such an insurer's balance sheet.

The laws of all states require companies writing certain kinds of insurance, such as fire and property, to maintain uuearned premiun reserves. See R. MEHR \& E. CAMMACK, Principles of Insurance 829 (41h ed. 1966). See also Mich. Comp. Laws $\$ 500.808$ (Supp. 1975).

17. See Hofflander, Minimum Capital and Surplus Requirements for Multiple Line Insurance Companies: A New Approach, in InsUrance, Government aNd SOCIAL Policy, supra note 15, at 69; R. KenNEY, FundaMentals of FIRE AND Casualty STRENGTH (4th ed. 1967). For a criticism of use of the ratio of premium written to surplus as a test of financial solidity, see Beckman \& Tremelling, The Relationship Between Net Premium Written and Policyholders' Surplus, 59 Proceedings Casualtx AcTUARIaL Soc. 203 (1972). For a simplified numerical analysis of the effects of premiun volume on surplus, see R. Hensley, CompettTion, Rkgulation, AND tHe PUBLIC INTEREST IN NONLIFE INBURANCE 160 (1962).

18. Profit and loss in the insurance industry is essentially a product of four factors. Income is derived from underwriting profits (i.e., earned premiums) and return on investments; expenses are incurred through the cost of operations and payment of policyholder losses. Net loss is simply the excess of expenses over income for any period. See generally R. HENSLEY, supra note 17, at 171 et seq.

19. Unearned premium reserves are "recaptured" from their separate liability status with the passage of time. For example, a one-year policy with a $\$ 120$ premium is wholly a liability ou the date the insurance takes effect. Three months later, however, $\$ 30$ has been recaptured to pay expenses, and $\$ 90$ remains in the liability (unearned premiuin reserve) account. See R. MEHR \& E. CAMMack, supra note 16, at 845.

20. For a recent general discussion of factors which influence this relationship, see Forbes, Capital and Surplus Formation in the Nonlife Insurance Industry, 1956-70, 14 Q. Rev. Econ. \& Bus. 15 (Autumn 1974). 
writings, and that ultimate limit is called "capacity" in the insurance lexicon. ${ }^{21}$

But money is both fungible and fluid, and in real life the practical capacity of the insurance markets to supply the demand for particular insurance coverages is not so much a function of the ultimate financial limit described above as it is of a complex of managerial decisions as to the allocation of capital and other corporate resources.

Crass though it may seem, profitability is the critical, though not the exclusive, factor in this decision-making. ${ }^{22}$ The insurance enterprise, whether thought of as an individual company or as the aggregate of all insurers, can preserve and expand the surplus necessary to meet the growing appetite of our society for insurance coverages of every type only by profitable operations. Profits both directly contribute to surplus and make it possible to attract additional capital from other sources. Though the proposition is so obvious that we hesitate to risk giving needless offense by openly stating it, the unfortunate historical fact is that large segments of the public, many politicians, and an embarrassingly large number of people intimately connected with the insurance busimess have behaved as if it were not true.

An insurer can derive profits in two ways-from underwriting operations which result in a combination of losses and expenses less than the amount of premiums received, and from favorable results in the investment of funds under the control of the insurer. Insurers also can lose money on both the underwriting and investment sides of the business.

During the past twenty years, underwriting results in the property and casualty busimess have been uneven in time, by line, and geographically. ${ }^{23}$ There have been long stretches in which many imsurers have experienced heavy underwriting losses in lines, such as automobile

21. See Hershbarger, Insurance Underwriting Capacity: A Psychometric Appraach, 42 J. RisK \& INs. 51, 52-53 (1975); R. HENSLEY, supra note 17, at 156 et seq.

22. See Ehre, Is There an Insurance Capacity Crisis?, 33 J. INs. 8, 10 (Mar./Apr. 1972); Johnson, Seamanship for the 70's, 35 J. INs. 8, 11 (Sept./Oct. 1974). For the development of one profit-maximizing model for insurers, see Spellman, Witt \& Rentz, Investment Income and Non-Life Insurance Pricing, 42 J. Risk \& INs. 567 (1975).

The profitability factor plays its weightiest role during times of insufficient capacity to meet the demand for insurance, as in the post-World War II period in the United States. See R. MEHR \& E. CAMMACr, supra note 16, at 845.

23. See Kinder, $A$ Look at the Leaders: Was Anyone A Winner in 1974?, Best's REv., PRop./LIABIITY INs. 18 (July 1975). Cf. Bateman, The Prospect Before Us, 33 J. INs. 2, 3 (July/Aug. 1972); Menist, The Future Begins Today, 33 J. INs. 2 (Mar./Apr. 1972). For new data on industry performance, see BeST's AGgregates \& AVERAGES (Liability and Property). 
insurance, ${ }^{24}$ which constitute important segments of the total market. For most of the same period of time, however, underwritimg losses have been offset by investment gains. ${ }^{25}$ There have been few periods when insurers generally have experienced broad underwriting losses and adverse investment results at the same time.

In the sensible econoumics of times gone by, there probably was logic to the historical pattern. The technique of imsurance ratemaking (with its emphasis on past experience as the chief basis for predicting costs), coupled with competitive euphoria and regulatory lag, causes inflation to have deadly effects on underwriting results. But in the past that same inflation tended to be accompanied by increases in the value of equity securities in which property-casualty insurers invested larger and larger proportions of their portfolios.

The emergence of the perverse economics of the 1970s, with inflation and recession occurring together for an extended period of time and even to soine extent causing each other, ${ }^{26}$ has destroyed the comfort derived by insurance managements and insurance regulators from the familiar stabilizing effect of the alternating economic swings in underwriting and investment results. The years 1974 and 1975 have been underwritimg and investinent disasters for the property and casualty insurance business unparalleled since the 1930s, if ever. ${ }^{27}$

The effect of these events on the psychology of imsurer managements cannot be underestimated. Gone is the heavy orientation toward volume at all costs which had resulted from over-reliance on the equity investment gains to be derived from cash-flow expansion. In a word, there is present in the insurance busimess a pervasive "Back to Basics" movement. And the basic principle which the managers have discovered is that those who wish to endure in the business of writing imsur-

24. Automobile insurers experienced a $\$ 1.4$ billion underwriting loss during the decade of the 1960s. Johnson, supra note 22, at 9.

25. See Levey, Balancing Investment and Underwriting Risks, 76 BEST's Rev., Prop./LiabIIITY INs. 10 (Sept. 1975); cf. Forbes, supra note 20.

26. Council of Economic Advisors, Economic Report of the President 19 (Feb. 1975).

27. The property and casualty insurance industry lost more than $\$ 2.5$ billion in 1974. 1974 Underwriting Results By Line of Business, Best's REv., Prop./LIABIIITY INs. 10 (May 1975). See Herman, Damage Insurers Hit by Losses on Stocks, Rise in Claim Amounts, Wall Street J., Jan. 20, 1975, at 1, col. 6. The industry performance in 1975 was expected to be at least as dismal, with loss estimates ranging as high as $\$ 4$ billion. Daenzer, $A$ Look Into the Future, Best's Rev., Prop./Liabinty Ins. 26 (Dec. 1975); Walker, Looking Behind the Property/Liability Bloodbath, Best's Rev., Prop./ LiabILITY INs. 21 (Nov. 1975); 79 NATIONAL UNDERWRITER, Sept. 19, 1975, at 1. 
ance contracts must sell those contracts for prices which are adequate to cover the attendant losses and expenses. ${ }^{28}$

\section{Malpractice Insurance}

Medical malpractice insurance is simply a specialized form of liability imsurance. Although there are specialty carriers writing only this coverage, ${ }^{29}$ most of it is written by large multiple-line property and casualty insurers. ${ }^{30}$ Those insurers write or have the opportunity to write a wide variety of insurance coverages both in the personal and commercial markets. Insurance lines may be classified not only by reference to the type of risk insured, such as fire, legal liability, interruption of business, theft, or defalcation, but also by reference to the nature of the activities or properties from which the risks of loss arise. The writing of fire insurance, for example, on urban residences, farms, cheese factories, and lumber mills constitutes disparate insuring operations each requiring some degree of specialized organizational competence. The design of policy forms, the development of rates, the evaluation of risks, the orientation of the marketing force, and the adjustment of losses all require functional specialization of an insurer's persolmel directed toward the particular circumstances of the subject areas in which writimgs are concentrated. If one wants to write fire insurance on cheese factories, and wind up with more unoney than grilled cheese, it is helpful to know a good deal about the cheese business.

The writing of any specialty line of coverage requires the allocation of resources to develop the competence to handle the line. It also requires the willingness to absorb the increments to the general expenses and the losses of the imsurance operation which the specialization of function imposes until such time as it may be supposed that the line will generate a sufficient volume of premiums at rates adequate to carry those expenses and losses. Given the enormous technical and legal complexities involved, the foregoing principles are preeminently applicable to the writing of insurance against the occupational liabilities of individuals and institutions engaged in providing health care.

28. See A.M. Best Co., Comment on the State of and Prospects for the Property/ Liability Insurance Industry, BesT's REv., Prop./LIABHITY INs. 10, 90-91 (June 1975); Walker, supra note 27 , at $24,78$.

29. One such specialty carrier is Medical Protective Company. Hendricks, What Your Next Malpractice Policy May Look Like, MED. EcoN., Apr. 14, 1975, at 29, 30.

30. See Hastings, Medical Malpractice Background Paper, in STAFF of CoMM. on INTERSTATE AND FOREIGN COMMERCE, supra note 1, at 16; Kendall \& Haldi, The Medical Malpractice Insurance Market, in MeDICAL MALPRACTICE REPORT Appendix 522. 
One further observation is appropriate concerning the attitudes of insurer managements or, indeed, of anyone else trying to make profitable choices among competing alternatives for the commitment of limited capital and human resources. The managers are prone to view profitability in relation to an assessment of investment risk, meaning the perceived degree of uncertainty as to the desired outcome. ${ }^{31}$ The greater the risk, the higher will be the projected rate of return necessary to induce a decision to commit capital and other limited resources to that venture rather than to some other one seen as promising more certain gain.

In the "Back to Basics" climate of insurer management these days, ${ }^{32}$ it is understandable that relative certaimty and predictive stability in underwriting results may be much prized as a characteristic of any line. This is particularly true because historical experience has tended to inake insurer managements skeptical about the feasibility of ever deriving really substantial underwriting profits for very long on any of the major, publicly sensitive classes of property or casualty insurance. A combination of regulatory, competitive, and political pressures effectively stifles the opportunity for sustamed yield of high underwriting profits, at least for the industry as a whole. The property and casualty insurance business, whatever it may once have been, is not now to be counted anong the industries where one is encouraged to risk disaster by the lure of making a killing.

In this hight, it is fair to inquire into the experience which the property and casualty insurers have had with inedical malpractice insurance and into the types of problems insurance managers may perceive in it.

\section{The Development of Rates for Malpractice Insurance}

The principal coverage with which we are concerned is Physicians Malpractice Insurance, also known as the Medical Professional Liability Policy. As generally written today, it is a very broad and unexceptional form of insurance against costs of defense and liability for damages arising out of the rendering or failure to render the described professional services during the policy period. ${ }^{33}$ In addition to the basic coverage

31. See generally V. Brudney \& M. Chirelstein, Cases and Materials on Corporate Finance 56-66 (1972); B. Graham, D. Dodd \& S. Cottle, Security Analysis 48-52, 664-65 (4th ed. 1962).

32. See note 28 supra and accompanying text.

33. A typical insuring clause reads as follows:

Payment on behalf of the imsured because of injury arising out of:

(a) malpractice, error, or mistake in rendering or failing to render professional services in the practice of the insured's profession committed during the 
for the liabilities arising from the professional conduct of the individual pliysician insured, the policy also covers the vicarious liability of the physician for the professional acts or omissions of others for whoin the physician is legally responsible by reason of a relationship such as that of employer and employee. ${ }^{34}$ This is not an "omnibus clause,"35 and does not extend the insurance protection to the other person but rather is intended only to cover the vicarious liability of the named insured. Finally, the form specifically provides coverage for liabilities arising from the insured's participation in professionally related collective activities such as inembership on institutional staff committees and accreditation boards. ${ }^{36}$

In the usual form, there are only two specified exclusions from the coverage. The first is for the vicarious liability of the physician as a inember of a partnership, stated as an exception in the imsurimg clause. ${ }^{37}$ The second is a specific exclusion from the policy of the liability of the insured as owner or executive official of a hospital, sanitarium, inpatient clinic, laboratory, or business enterprise. Both of these are intended to avoid duplication of coverages ordinarily provided under other commonly extant policies. However, it is comnon to extend the coverage of the individual policy, either by endorsennent or other policy provision, to the physician's partnership liability, ${ }^{38}$ and recently to the liability of his professional corporation.

There are, of course, variations in policy coverage and language and some forms are more restrictive. However, we think the foregoing describes a typical coverage and suggests the breadth of the coverage which has evolved in response to the needs of the physicians.

policy period by the insured or any other person for whose acts or omissions the insured is legally liable;

(b) acts or omissions committed by the insured during the policy period as a meinber of a formal accreditation or similar professional board or coinmittee of a hospital or professional society. Parish, Professional Liability Insurance, in PROPERTY AND LIABILITY INSURANCE HANDBOOK 478, 484 (J. Long \& D. Gregg eds. 1965).

Other examples of insuring clauses can be found in 1 R. LONG, THE LAW OF LIABILITY Insurance $\$ 12.02$ (1975); 2 D. Louisell \& H. Williams, Medical Malpractice $\pi$ 20.03, at 589 n.25 (1974); McNeal, Patients, Litigation and Patience, 33 Ins. CounseL J. 408 (1966).

34. See note 33 supra.

35. An omnibus clause extends protection to persons other than the named insured, under specified circumstances. It is seen frequently in autoinobile liability policies. 1 R. LoNG, supra note 33, § 3.01. See generally Ratcliffe, The Omnibus Clause, 39 J. RisK \& INS. 457 (1972).

36. See note 33 supra.

37. For an example of such an exclusion, see Shehee v. Aetna Casualty \& Surety Co., 122 F. Supp. 1, 7 (W.D. La. 1954). See also 1 R. LoNg, supra note 33, § 12.03.

38. See 1 R. LoNG, supra note 33. 
An obvious characteristic of insurance is that ordinarily the price is set before the cost is known. In medical malpractice insurance the cost is not known for a very, very long time. For a variety of reasons the discovery, assertion, and eventual disposition of inalpractice claims tends to stretch over a period of many years after the close of the period of policy coverage. ${ }^{30}$ In addition, the experience of the past ten years has shown that the pattern of frequency and cost of claims as they emerged were not susceptible to prediction by accepted and systematic actuarial techniques. ${ }^{40}$

An understanding of the problens involved in the pricing of malpractice insurance may be aided by a description of the actuarial concepts and methods employed and the difficulties which the actuaries encounter in this line. ${ }^{41}$

The procedures of the actuary are conceptually simple. He starts with a body of past experience sufficient to make him feel comfortable about the "credibility" of the data. ${ }^{42}$ He brings the premium component of the experience to "current level," i.e. the dollars that the exposures or insured entities would generate at today's rate schedules. $\mathrm{He}$ may do this by factoring the historical premiums to account for rate changes imposed between then and now, or he inay more accurately deal with the historical exposures and rerate them at today's prices, a process called "extending exposures at current level." 43 Then he turns his attention to the losses. His concern is how these losses would look if they were incurred during the period when the new rates to be produced will be in effect. He adjusts the historical losses im two ways. First he .

39. Medical Malpractice Report 42; Rudov, Myers \& Mirabella, Medical Malpractice Insurance Claims Files Closed in 1970, in MediCAL MALPRACTICE REPORT Appendix 1,9. A representative of a professional liability insurer covering New York physicians reported that less than half the losses incurred in a given policy year had been finally determined five years later, and that a "substantial number" reinained undetermined ten years after occurrence. House SUBCOMM. ON HEAITH AND THE ENVIRONMENT, supra note 2, at 14 (Remarks of John Linster). See also id. at 12 (Remarks of Warren Cooper).

40. Medical Malpractice Report 41-42; Gibbs, Medical Malpractice Insurance Crisis, 80 Case \& CoMment 8, 11 (1975).

41. For a general discussion of actuarial practice in inedical professional hability, see Kendall \& Haldi, supra note 30, at 529-33.

42. For discussions of the importance of credibility in the msurance context, see Mayerson, The Uses of Credibility in Property Insurance Ratemaking, 27 GroRNALE Dell' Istituto Italiano Degli ATruari 197 (1964). See also Bailey, Credibility Procedures, 37 Proceedings Casualty Actuarial Soc. 7 (1950); Longley-Cook, An Introduction to Credibility Theory, 49 Procendings Casualty Actuarial Soc. 194 (1962); Mayerson, A Bayesian View of Credibility, 51 Proceedings Casualty ACtuarual Soc. 85 (1964).

43. Cf. Kendall \& Haldi, supra note 30 , at 531 . 
"develops" them; that is, he accounts for reserve deficiencies or redundancies and estimates what the historical losses will amount to when they are all paid. ${ }^{44}$ He then turns his attention to what will probably happen if these developed losses are paid some years later, as will be the case under future rates. To quantify this consideration he uses a "trend" factor, ${ }^{45}$ a very important calculation when inflation, changes in the legal environment, and similar forces produce volatile loss costs, in order to project the historical losses to a point in time when future losses are expected to occur.

Froin the premiums under current rates, and his estimate of future loss values that these rates are calculated to cover, the actuary next calculates a loss ratio at current rates. By looking at known non-loss costs as a function of past premiums and adjusting for expected or known future changes, he can predict what percentage of future rates will be needed to pay such non-loss expenses. The remainder is what will be available to pay future losses, and is called the "expected loss ratio." For instance, if expenses are estimated at twenty percent, eighty percent of the future rate is available to pay claims.

The actuary next compares the loss ratio at current rates with the expected loss ratio. If the former is the greater, rates must be raised to provide the necessary dollars to pay future losses. Let us return to our example. If the expected ratio is eighty percent and the ratio at current rates is 100 percent, the rates inust be raised by twenty-five percent. Consider an average premium of $\$ 100$ under current rates. In this example it would lead to $\$ 100$ of future loss, but this leaves the insurer no money to pay non-loss expenses. If the rates are raised to $\$ 125$, a twenty-five percent increase, then eighty percent is $\$ 100$, the amount necessary for loss, and the other twenty percent of $\$ 25$ is available for non-loss expense. ${ }^{46}$ In like maimer, if the expected ratio is the greater, rates should be decreased.

44. See Lange, General Liability Insurance Ratemaking, 53 ProceEdngs Casualty Actuarial Soc. 26, 32 (1966). See also Cook, Trend and Loss Development Factors, 57 Proceedings Casualty Actuarial Soc. 1, 2-3 (1970); Stern, Ratemaking Procedures for Automobile Liability Insurance, 52 Proceednggs Casualty Actuarial Soc. 137, 162 (1965).

45. See Lange, supra note 44, at 32. See generally Cook, supra note 44.

46. Another actuary might prefer a different approach, called the "pure premium" method, which will lead him to the same result. A pure premium (perhaps better called a loss cost) is a technical term to denote the average premium that must be collected to pay for losses only, that is, a value that has no consideration for expense. It is calculated by dividing the loss by the number of exposures. In the present case, this second actuary will arrive at the developed, trended losses and divide by the historical exposure count. The value in our example will be $\$ 100$. Then he divides this by the expected loss ratio, eighty percent, in order to "load" the expected future premium for 
Actuarial calculations thus involve three technical considerations, credibility, development, and trending, which, while conceptually simple, may be quite complex in their derivation and computation. In some lines of insurance this trinity is well-defined, with rather standard procedures being generally accepted. Unfortunately, their definition in malpractice insurance is anything but clear. Let us take a look at why this is true.

First, as to credibility, the situation is alarmingly straightforward. In most cases credibility has not been theoretically defined. The larger state programs have by implication been considered fully credible (though there is little uniformity in the number of years to be used in the experience period), and even the experience of smaller states has been accorded credibility, although companywide (or bureauwide) adjustments are made for development and trend. The last represents an acknowledgment of lack of full credibility, but this nod is not a response to any mathematical theory.

The number of medical exposures and claims, the statistics which determine degrees of credibility, are miniscule in comparison with such lines as automobile or homeowners insurance. For example, consider the situation in a populous urban state, New Jersey. The rating bureau's most recent filings for private passenger automobiles displayed an annual count of about 1.1 million cars, ${ }^{47}$ while a companion liomeowners filing was based on an annual home count of about 700,000 units. ${ }^{48}$ In contrast, the company writing the medical society's program based its independently devised rates on an annual census of less than 7,000 doctors, ${ }^{40}$ with hospital rates calculated froin the experience of no more than 110 lrospitals. ${ }^{50}$ These comparisons are typical. Hence, the first major uncertainty arises from the fact that the value of past data in predicting future losses is mathematically ill-defined and unclear.

The second consideration is loss development, which can be viewed in two independent aspects. The first is what is known as "incurred but not reported" losses, usually abbreviated IBNR. ${ }^{51}$ In any type of

expense. The answer, of course, is an average premium of $\$ 125$, which breaks down to $\$ 100$ (eighty percent) for loss and $\$ 25$ (twenty percent) for expense. Houston, The Equivalence of the Pure Premium and the Loss Ratio Methods of Ratemaking, 23 J. RisK \& INS. 72 (1956). 1975.

47. Insurance Services Office, Filing with N.J. Insurance Dep't, effective Dec. 1975.

48. Insurance Services Office, Filing with N.J. Insurance Dep't, effective Aug.

49. Federal Insurance Co., Filing with N.J. Insurance Dep't, effective May 1975.

50. Insurance Services Office, Filing for N.J. Hospital Professional Liability Rates.

51. See generally Bornhuetter \& Ferguson, The Actuary and IBNR, 59 ProceEDINGS Casualty Actuarial Soc. 181 (1972); Tarbell, Incurred But Not Reported Claim Re- 
insurance these will be claims presented after a policy has expired, but their frequency is noticeably higher in the liability lines written on an "occurrence" basis. ${ }^{52}$ Clearly, there can be many reasons why a claimant may not discover an injury or press an early claim. The reasons for late discovery seem apparent; those for late suits are more difficult to perceive. Experience indicates that there are more reasons for delay in the area of medical malpractice than other forms of insurance. To illustrate the phenomenon of extended claims reporting (one of the main factors contributing to the "long tail"), ${ }^{53}$ statistics compiled by a major state insurance department are helpful..$^{54}$

$\begin{array}{cc}\begin{array}{c}\text { Months from the Beginning } \\ \text { of a Policy Year }\end{array} & \begin{array}{c}\text { Percent of Number } \\ \text { of Claims Reported }\end{array} \\ 24 & 38 \\ 36 & 67 \\ 48 & 79 \\ 72 & 86 \\ 84 & 91 \\ 96 & 93 \\ 108 & 95 \\ 120 & 96 \\ 132 & 98 \\ 144 & 99\end{array}$

When all policies are expired, the table shows that only thirty-eight percent of the claims have been reported; it is not until four years thereafter that ninety percent are reported to the company. There are two consequences to this. First, recent years of experience are all but meaningless since so little of the data is known as fact. The actuary thus loses the responsiveness to change that he cherishes in fresh data when he sets out to price the malpractice policy. Second, even when he deals with older years, the actuary must make substantial guesses as to

serves, 20 Procendings Casualty Actuarial Soc. 275 (1933-34), reprinted at 58 Proceedings Casualty Actuarial Soc. 84 (1972).

52. "Occurrence" means, simply, that the insurer providing liability coverage for a specified period of time, usually a year, is liable for any accidents that occurred during the period of time without regard to the date the claims are presented, subject, of course, to the appropriate statute of limitations. See New Form of Malpractice Liability Coverage to be. Offered to Doctors, in MaLpractice Digest 1 (St. Paul Fire and Marine Ins. Co., Jan./Feb. 1975).

53. See, e.g., Medical Malpractice Report 42. The term "long tail" refers to the length of time between the policy period and the final determination of losses.

54. Data inade available to the authors by participating private insurers.

55. The term "policy year" ineans experience on policies during a calendar year, for instance 1975. A policy issued on January 1, 1975, would expire on December 31, 1975, but a policy issued on December 31, 1975, would not expire until December 30, 1976. Thus, losses in a given "policy year" are spread over two calendar years. 
what is yet to be reported. For instance, working in 1975 looking at policy year 1971, he is aware of only two-thirds of the claims. It is this magnitude of uncertainty that distinguishes the malpractice line.

The second aspect of development is what is called "run-off" in insurance jargon. When a claim is reported to the company, a member of the claims staff, an examiner, sets up a case reserve against its future disposition. The reserve is the examiner's best estimate, based on current knowledge, of what the claim will cost when final payment is made. In many lines of insurance the period between initial report and disposition is relatively short, but in malpractice it can be a matter of several years, averaging in excess of three years. ${ }^{57}$ Given the nature of inflation and its effect on trend, ${ }^{58}$ it is unrealistic to think that examiners can accurately calculate future liabilities, even in those rare cases where the facts and allegations are known at first report. Generally, the original reserves in bulk are insufficient to cover ultimate payments, a fact which in and of itself does not frighten the actuarial mind-so long as the degree of insufficiency is predictable, i.e. the presence of welldefimed patterns in the past that can be imputed to the future. Unfortunately such consistency is not a hallmark of malpractice run-off. The reason may be a change in carriers, each of whose claims staff subscribes to a different philosophy of reserving. Or even where a single carrier's experience is used for ratemaking there may be shifts in reserve unargins as examiners make corrections in case reserves in the course of their continuing reviews of open claims files. In any event, the actuary, if not frightened, is at least concerned and unsure.

The third area of actuarial uncertainty is trend. Over the last several years, the frequency and size of claims have soared beyond any actuarial expectations entertained during these years. ${ }^{59}$ For instance, in Southern California the average size of a claim has jumped from less than $\$ 6,000$ in 1963 to over $\$ 12,000$ in 1969 , and is now estimated at about $\$ 30,000 .^{60}$ The frequency of claims has spiraled just as dramati-

56. "Run-off" is an estimate of a past reserve, and consists of actual future payments on known claims up to a given date, plus anticipated remaining future payments on known claims as of that given date. Skurnick, A Survey of Loss Reserving Methods, 60 Proceedings Casualty Actuarial Soc. 16, 21-22 (1973). After a sufficient time period, the run-off becomes fully accurate in most lines, either because all clains are settled prior to the given date or because the open claims can be accurately reserved. Id.

57. See Steves, Medical Malpractice in Perspective, 28 CPCU Annars 209, 212 (Dcc. 1975).

58. See note 45 supra and accompanying text.

59. See Steves, supra note 57 , at 213-15.

60. Data made available to the authors by private insurers. 
cally: nine out of 100 doctors had claims made against them in 1963 , twenty out of 100 in 1970 , perhaps thirty out of 100 today. ${ }^{61} \mathrm{Had}$ we been dealing with a consistent economic and legal inflation, our actuary could have predicted claims with some accuracy, but looking so far ahead as he must when pricing (due to the long tail) he cannot be blamed for not foreseeing that the rate of change in inflation was shifting. Indeed, in retrospect the rate of change was linear when the rates were made and became exponential when the clanns were received.

These three considerations-credibility, development, and trend -are substantially less defined and predictable in medical malpractice than in any other line, and inability to cope with thein has led the actuaries to their greatest failures. So much so, in fact, that the coinpany which is perhaps the largest writer of malpractice in the country, has declared the occurrence form unpriceable and has agreed to continue in the business only on a claims-made basis, by which it will cover only claims presented in the year of coverage. ${ }^{62}$ Such a form bobs the "tail" by eliminating clains (or at least incidents) imcurred but not reported during the policy year and by shortening the time between prediction and payment. Other carriers are simply leaving the business. ${ }^{63}$ The crisis in the availability of malpractice insurance is due only in part to past underwriting losses. Just as important is continuing and, perhaps, uninanageable uncertainty about future pricing.

\section{The Medical Insurance "CRISIs"}

We are told that the past is a prologue to the future. From an actuarial standpoint an unstable and unfortunate past does not portend well for the future. A number of factors have coinbined to cause malpractice liability costs to mcrease with unpredictable sharpness in recent years. A consideration of those factors in juxtaposition with the behavioral tendencies of insurers may suggest some helpful observations about the future.

\section{Causes}

Why has malpractice liability expanded so dranatically, both in the frequency and severity of claims? The first reason has to do with the

61. Id.

62. New Form of Malpractice Liability Coverage, supra note 52; N.Y. Times, Jan. 24, 1975, at 34, col. 1 .

63. Business Week, Jan. 12, 1976, at 60, 64; N.Y. Times, June 10, 1975, at 78, col. 1 ; id., June 3, 1975, at 22, col. 8; id., June 2, 1975, at 1, col. 1 . 
incidence of underlying loss. We do not doubt the validity of the oftmade claim for the excellence of American medical care, at least for those patients to whom it is financially ayailable. Medical education is as good as money can make it. Hospitals and laboratories are inagnificently equipped. New drugs and procedures are extensively tested before their general usage. Extensive research efforts produce an endless array of seemingly miraculous advances in technology. Yet we suspect that the incidence of actual loss, in the sense of the original definition we accorded to that term, ${ }^{64}$ is relatively high, probably higher than the volume of asserted malpractice claims indicates. ${ }^{65}$ Even if the juridical climate is as favorable to claimants as the provider groups contend, ${ }^{66}$ the neghigence hability system undoubtedly continues to exert a substantial filtering effect on claims. The technology of nodern medical care is incredibly complex. The total physiological effects of much that is done are not always known or understood. Many of the drugs and procedures employed involve narrow inargins between efficacy and dangerousness. Very large numbers of professionals of various types are engaged in the treatunent process and, for a single condition, the patient may be subjected to numerous professional and institutional contacts and decisions. Many physicians, technologists, and institutions have enormous patient contact loads and work under severe time pressures. ${ }^{67}$ And finally, almost by definition the exposed population largely consists of people who either have something wrong with them, or think that they do, and submit to processes which they rarely fully understand and under conditions which render them dependent and even helpless to contribute to their own safety. There is reason to

64. See text accompanying note 4 supra.

65. See O'Connell, Expanding No-Fault Beyond Auto Insurance: Some Proposals, 59 VA. L. REv. 749, 757 (1973); Steves, supra note 57, at 210-15.

66. For examples of physician attitudes in this context, see Masur, Malpractice Crisis, N.Y: State J. Med. 1554 (Aug. 1975); Wiseman, Res lpsa Loquitur, W.J. Med. 71 (July 1975). The same attitude is visible in statements by insurers. See House Subcomm. on Health and ENvironment of the Comm. on Interstate and Foreign COMMERCE, supra note 2, at 17 (Remarks of John Linster).

67. Meeting the nation's health manpower needs is a problem which has not escaped the attention of Congress. See Hearings on H.R. 2956, H.R. 2957, H.R. 2958, and H.R. 3279 Before the Subcomm. on Health and the Environment of the House Comm. on Interstate and Foreign Commerce, 94th Cong., 1st Sess. ser. 94-3. (1975); Hearings on S. 3585 Before the Subcomm. on Health of the Senate Comm. on Labor and Public Welfare, 93d Cong., 2d Sess., pt. 3 (1974). See generally Ruhe, Recent Events of Special Interest to Medical Education, 234 J.A.M.A. 1326, 1328 (1975). The implementation of a national health insurance program would likely have some impact on physician workload; however, it is not at all clear whether such a plan would increase or decrease the working hours of the physician. See Enterhine, McDonald, McDonald, et al., Physician's Working Hours and Patients Seen Before and After National Health Insurance: "Free" Medical Care and Medical Practice, 13 MED. CARE 95 (1975). 
believe that the incidence of error, much of it undoubtedly harmless and most of it not morally blameworthy, is higher than we would like to believe. ${ }^{68}$

The second important factor is the extent to which the compensation process results in the transinutation of inedical injury losses into liability claims costs. This is a function of the combined and imteractive effect of legal doctrine and the behavior of claimants and their lawyers in asserting claims, of insurers' representatives im settling or defending thein, and of judges and juries in deciding contested cases. At an earlier time, not so long ago, successful recovery on inedical inalpractice claims was difficult due to the substantial barriers erected by the conventional requirements of the tort law doctrines and the obstacles in acquiring knowledge of the technical facts imvolved and in securing the requisite professional testimony. Moreover, patient expectations were more modest and there was less propensity to assert claims. The total process had the effect of suppressing and filtering the extent to which medical injury losses became translated into compensated liability claims.

Over the past twenty-five years, however, there has been a dramatic and apparently accelerating change in this state of affairs. The various factors are chronicled elsewhere in this Synposiun and need not be analyzed here but the litany has become a familiar one: res ipsa loquitur, informed consent, breaches in the locality rule, greater availability of expert witnesses, relaxation in the application of the statutes of limitations, expansion of doctrines facilitating multiple defendant liability, open discovery, more sophisticated claimants' lawyers, enhanced public claims consciousness and a prevalent expectation of in-

68. Two recent studies indicate serious deficiencies in the quality of medical care. A 1973-75 study made by the American College of Surgeons and the American Surgical Association indicated that 796 of the 1,696 "untoward incidents" arising out of 1,493 surgical operations were avoidable. Eiglty-five deaths were deemed avoidable. Child, The Critical Incident Study of Surgical Deaths and Complications, 1973-1975 (10th and final SOSSUS Report in the Study of Surgical Sciences for the United States), discussed in Quality of Surgery Unveiled, MED. WORLD NEws, Jan. 26, 1976, at 24. See also Cohn, Surgical 'Tncidents' Held Avoidable, Washington Post, Jan. 22, 1976, at 1, col. 1.

The results of a "self-assessment test" taken voluntarily by 4,513 plysicians indicated serious deficiencies of knowledge and a need for further education in the use of antibiotics. The mean correct score on the National Antibiotic Therapy Test was sixtyeight percent. Neu \& Howrey, Testing the Physician's Knowledge of Antibiotic Use, 293 New ENG. J. MEd. 1291 (1975).

These quality-of-care studies are reflective of the results reached in a number of earlier studies. See Brook, Brutoco \& Williams, The Relationship Between Medical Malpractice and Quality of Care, 1975 Duke L.J. 1197. See also Pocincki, Dogger \& Schwartz, The Incidence of Iatrogenic Injuries, Medical MaLPRACTICE RePort Appendix 50,55 . 
fallibility of the professionals and their miraculous technology, etc. The cumulative effect of these changes in legal and cultural attitudes and behavior has been a rapid evolution from suppression and filtration toward encouragement and facilitation in the compensation of medical injury losses through the insured tort system. In contemporary personal imjury law "negligence" often has little relation to inoral culpability and many claims are founded on the adverse consequences of routine error and failure in the manipulation of the complex devices and processes which dangerously abound in our technological and inechanized society. Given the volume of: underlying losses and the tendency toward a general public expectation of assured results of professional performance, it is not likely that the trend in the volume and severity of claims will be reversed.

In this climate, insurer managements, painfully aware of the extent to which they liave repeatedly underestimated the trend of development in the past and pressed by capacity needs to achieve consistent underwriting soundness, may be expected to react to the uncertain future by assuming that the trend will be in the direction of more claims and awards arising from the failures of medical procedures to accomplish desired results and to price the insurance accordingly.

\section{Prescriptions}

The purpose and obligation of this Article is to describe the medical malpractice insurance problem in its insurance aspect, not to prescribe solutions for it. Nevertheless, a few observations seem to flow quite naturally from the preceding analysis of the situation.

The most basic and obvious observation is that the subject of handling medical losses is far larger than its liability insurance aspect. While insurance is often the device by which the costs of medical losses are made most vivid to providers and patients, so that (as in the current furor) dislocations in the liandling of medical losses can be superficially perceived as solely insurance problems, any systematic approacl to the subject must include its medical, legal, moral, and other aspects as well as those of insurance.

Whatever we do now, a goodly amount of inodesty and, indeed, resignation is definitely called for. Since there is no longer any question that the frequency and size of malpractice awards will continue to increase so long as the present system remains intact, it follows that a larger part of the cost of lealth care will liave to be devoted to paying medical losses than was the case in the past.

It follows, that is, unless society singles out one or more of the 
participants in the medical loss system for expropriation. A balanced solution, designed to reduce loss costs by nodifying the rights and duties of many or all of the participants in the system, is one approach, and a quite reasonable and not unlikely one. However, for any one of the involved interest groups to seek to save its own interests by trampling on the interests of other participants in the system is quite another matter. Nor is the latter unheard of in the current excitement. With that in mind, one should view with skepticism legal changes which would unfairly force loss costs back onto the patient, ${ }^{69}$ insurance capacity changes which would force insurers to subsidize the system, ${ }^{70}$ or insurance coverage changes which would unfairly leave the physician unprotected and the patient uncompensated.

Assuming that society is dissatisfied with the present level and allocation of inedical loss costs, a balanced approach to the problem might consist of three parts; the first two are beyond the scope of this Article, the third is the insurance aspect.

The first part would be better control of medical losses themselves. It cannot be questioned that many of today's insured medical losses result from the failure of some health care professionals to meet the standards of professional competence to which society quite justly holds them. Some of these situations would seem to be avoidable by, for example, tighter regulation of health care providers, peer review in questionable cases, and closer surveillance by medical societies and practicing physicians' groups.

The second would be to re-examine the legal rules governing the right to recover for medical losses and the amount of that recovery, as well as the role and compensation of the legal profession in the medical loss cost-allocation system. This re-examination would certainly have to include such questions as limitations on recovery for pain and suffering, limitations on contingent fees for attorneys, and modification of the rule that damages are to be measured without regard to funds received from collateral sources. ${ }^{71}$

69. See Havighurst, "Medical Adversity Insurance"-Has Its Time Come?, 1975 DUkB L.J. 1233. For a discussion of state legislative limitations on provider liability or patient recovery, see Comment, State Legislative Responses, supra note 1, at 1418-24.

70. North Carolina has ordered all general liability insurers authorized to write coverage in the state to participate in a reinsurance program for inedical professional liability. N.C. GeN. Stat. \$§ 58-173.34 to .51 (1975 Supp.). The statute has been challenged by insurers, and a state court has found the plan unconstitutional. State Farm Mutual Ins. Co. v. Ingram, 44 U.S.L.W. 2255 (N.C. Super. Ct., Dec. 9, 1975).

71. For a discussion of recent state legislative developments in these areas, see Comment, State Legislative Responses, supra note 1, at 1442-50.

We recognize that all of these possibilities involve troublesome questions of overall 
The third part of a balanced solution concerns insurance and, in turn, consists of two aspects. The first is designed to reduce the uncertainty in malpractice liability ratemaking, both in the interest of fairness to insured and insurer and in the interest of reducing the uncertainty as to financial result which has made insurer managements so fearful of this line. It merely involves applying to the malpractice situation the familiar insurance techniques of policyholder dividends or retrospective, experienced-based rating. These techniques are widely used in large commercial property and casualty coverages today, ${ }^{72}$ and, indeed, have been used on a small scale in medical malpractice itself. Granted that the "long tail" of medical malpractice losses renders the making of rates most inexact and susceptible to huge errors, ${ }^{73}$ this approach would simply involve setting the initial presnium rate at the higil end of everyone's best guess as to the correct rate and then, after a suitable loss development period and pursuant to prior agreement as to the ultimate profit or loss to the insurer, having the insurer refund to the

legal policy. Of paramount concern is the question of the propriety of singling out the area of health care provider liability for extraordinarily favorable legal treatment. If these measures are sound limitations on medical malpractice liability, then why are they not equally appropriate as limitations on claims against product manufacturers, lawyers, plumbers, or automobile drivers? After all, the dispersal of the costs ultimately to the public as a whole is not likely to be demonstrably different.

The related questions of limitation on general, or "pain and suffering" damages, and on contingent fees pointedly pose the issue. Clearly, these features of the legal process in personal harm cases create opportunities for jury awards far in excess of economic loss and strong incentives for lawyers to pursue those opportunities energetically. And the large element of "juridical liazard" with which the liability and damage issues in these cases are infected significantly affects the settlement practices of insurers. A substantial portion of the recoveries through this system goes to lawyers. See Dietz, Baird \& Berul, The Medical Malpractice Legal System, in Medical Malpractice Report Appendix 87, 105-06. We recognize, therefore, that the right to unlimited pain and suffering damages, coupled with the contingent fee system, creates a situation which is susceptible to abuse and in some cases may foster undesirable behavior by lawyers, claimants, and insurers. Yet we should honestly admit that to single out the medical profession as beneficiary of special immunities from pursuit by lawyers does seem to establish a ring of protection around what must be our country's highest paid profession, simply to protect it from the alleged depredations of another of the country's higliest paid professions. If we want to solve these problems, as we should, we should do so systematically and not subject by subject. Thus, in "solving" the contingent fee problem, one has to come to grips with the reasons for its existence. Liability cases, particularly in techmical and professional fields, require the expenditure of considerable time, effort and inoney by claimants' attorneys. Until our society is prepared to find other ways of assuring that lawyers who represent claimants will be reasonably compensated in all cases, drastic limitation of contingent fees may lead to effective denial of representation in many cases.

72. See R. Mehr \& E. Cammack, supra note 16 , at $812-15$; J. Magee \& D. BickelHAUPT, GENERAL INSURANCE 435-36 (7th ed. 1964).

73. See notes 51-63 supra and accompanying text. 
insured physician, medical society, medical group, or whatever, the amount of premium that was left over after the losses were paid. While mechanically rather complex, this approach is conceptually simple and would seem to have the desired effect of having the insured profession carry its own liability costs, without the capitalization and management problems which beset attempts by physicians to organize a mutual company themselves. ${ }^{74}$

The foregoing insurance rating approach might well be coupled with a coverage change which would offer some hope of controlling losses as well as paying for them. Such a change is somewhat beyond the knowledge of the writers of this Article, but its general outlines would be as follows. A large portion of malpractice claims arise out of procedures performed im hospitals. ${ }^{75}$ Hospitals carry malpractice insurance and it would be possible to provide by law that the hospital's insurance must cover any claim arising out of a hospital procedure, that the physician's imsurance would not apply, and that the hospital would have no claim against the physician. Hospitals are large imstitutions better able to withstand financial shocks than are individual practitioners. They are the best instrumentality we now have for policing the professional conduct of physicians, and the contemplated insurance change would give them every incentive to be more vigilant. Fimally, their institutional continuity would suit them better than an individual practitioner to the sort of long-term retrospective rating program described above. ${ }^{76}$

As the reader can see from the analysis in this Article of the insurance aspects of the medical malpractice problem, as well as from the other articles in this issue, all that is certain about our three proposals is that they would leave a great many people quite unhappy. Fortunately, however, the problem is today the object of so much raging discontent that those dissatisfied with our, or any other, moderately reasonable program could scarcely be more numerous, more vigorous, or more vocal than they are today. As we noted at the outset, the medical malpractice insurance problem is not complex; it is merely intractable.

74. Mutual companies have been formed in San Francisco and Los Angeles, Survey Shows Gains in Liability Legislation, But Problems Remain, AM. MEd. News, Jan. 12, 1976, at 9, and similar attempts are underway in many other areas. Id. at 9-13.

75. Rudov, Myers \& Mirabella, supra note 39, at 10.

76. See Steves, $A$ Proposal to Improve the Cost to Benefit Relationship in the Medical Professional Liability Insurance System, 1975 DukE L.J. 1305, 1325. 
$$
\text { . }
$$ 